\title{
APPLICATION OF INFORMATION AND COMMUNICATION TECHNOLOGY IN TEACHING GRADE XI AND XII PHYSICS
}

\author{
Saad Muzaffar ${ }^{1}$, Muhammad Yousuf Sharjeel $^{2}$ \\ ${ }^{1}$ Mr., National University of Modern Languages, Karachi Campus, Pakistan, \\ saadmuzaffar@numl.edu.pk \\ 2Prof. Dr., Hamdard University, Pakistan, yousufsharjeel@hotmail.com
}

\begin{abstract}
This paper contains the discussion and finding about the application of Information and communication technology in teaching grade $X I$ and $X I I$ physics as compare to the traditional physics teaching. This descriptive study was based on the perception of physics lecturers and subject experts of grade XI and XII of public and private sector colleges and higher secondary schools of Karachi region. The sample of this study was the lecturers and subject experts of grade XI and XII of public and private sector colleges and higher secondary schools of Karachi. The researcher visited both the sectors to collect data in terms of questionnaire filled by the lecturers and subject experts. To determine the score of the questionnaire the researcher used 'Likert scale' with the category as strongly agree, agree, not sure, disagree and strongly disagree as 1,2,3,4 and 5. Levene's test was also used to check the quality of variance and $t$ - test used for the equality of means. Regression and correlation was also calculated by using SPSS 15.

This research proves that the ICT - based physics teaching becomes more effective and more content base which can very helpful in teaching of grade XI and XII public and private sector colleges and higher secondary schools' physics subject experts. From the outcomes of 'Levene's test' for value of 'F' and tables of group statistics it also is proved that it can also very helpful in project development of students. ICT based physics teaching can also very helpful in explaining of complex articles and phenomena's which can be difficult to understand by traditional based physics teaching. The researcher recommended that the public and private sector educational institutes and their management provide necessary requirement for the implementation of ICT - based physics teaching in terms of skilled and experienced subject experts and lecturers in their institutions. The researcher also recommended the Government of Sindh and the concern authorities to play their role in the implementation of ICT - based physics teaching and provide basic infrastructure and facilities to the educational instates all over the province of Sindh.
\end{abstract}

Keywords: Information and communication technology, Traditional Physics Teaching, Likert scale, Levene's test, SPSS 15

\section{INTRODUCTION}

The teaching methods of physics at secondary schools level as well as university level always face a critical 
stage in the development of its concepts and theories. In the traditional way of physics teaching it is difficult to explain the concepts and theories in a better way of understanding.

The application of information and communication technology is considered as a teaching and learning tool for both students and teachers because it is helpful to acquire the conceptual pedagogy and knowledge of physics. Research proves that with the help of this technology, different complex theoretical phenomenon can be explained easily. In a research 'The Impact of Information and Communication technology in teaching and learning Physics ', Adeyemo (2010) indicates that this technology has a great impact on learning and teaching physics.

\subsection{Review of Related Literature}

Physics is that branch of science that mostly students find difficult to understand so that the mostly students achieve less marks as compare to other science subjects. Akintunde and Aina (2013) indicate that students usually perform badly in physics as compare to other science subjects in every level of education. Many other researchers like Aiyelabegan (2003), Akanbi (2003), Aigbomian (1994) also supported this view that students of physics performed poorly. Adeyemo (2010) observed that a major reason of poor performance of students in physics is that physics is not to be separated from the basic cause of nature therefore teaching of physics at school level not encourage the students to understand therefore some instructional material is required in teaching and better understanding and facilitate student's interest in learning and understanding. Isola, Olosunde, Ojebisi and Oladejo (2011) states that the mastery of concepts of physics cannot be completely uncovered without using available instructional materials such ICT and its components.

Lim, C.P. (2007) conducted a study for examine and analyze the impact of application of information and communication technology (ICT) in the schools of Singapore. The conclusion of the study reflects that the sue of ICT in teaching at school level produce a positive impact as it is helpful to enhance the learning capability of students' as compared to the traditional way of teaching.

Schauer, Cernansky, Ozvoldova, Lusting (2007) define the importance of ICT in teaching and learning physics as the development of this technology make possible to introduce a new way of teaching and learning known a as 'Integrated e -learning (INT e-L). This new strategy of teaching physics based on the methods of science which are used to cognate science with the new world. This attractive way of teaching and learning physics based on the observation of the real-world experiments and phenomena with the help of e-simulations and e-experiments which are based on the basic laws and principals of physics and can be explain comfortably by e-teaching which provide almost every information such as e-textbooks, instructions, manuals.

Beata Jarosievitz of Hungry explains the importance of Information and Communication Technology with the combination of project method which makes natural science more attractive for the learners.

In a project 'Education of teachers in ICT application for teaching Physics at primary and secondary schools', Kainzova, Vysin, Riha, Holubova (2008) indicates that the using of ICT becomes very useful as an instructional agent in the age of technology. With the help of this technology we can find new teaching possibilities for better understanding.

In $20^{\text {th }}$ international academic conference, Madrid, (2015) Chalopatham, Phon-noi, Ployduangrat, presented their paper about the importance of ICT for the competency of teaching professionals. According to them the knowledge of ICT is very helpful in the course designing, develop knowledge of communication with each other. It also develops attitude for desire to know, provide guide line to solve the problems and develop coordination and confidence between the teachers and students. Jin and Lee presented their research paper in $17^{\text {th }}$ International Academic Conference, Vienna (2015). In this paper they presented that the application of ICT - based education helps in enhancing the learning capabilities of gifted students in science studies.

Comi, Gui, Origo, Pagani, \& Argentin, (2016) in their research paper found that computer-based teaching method becomes helpful to increase students' performance by helping teachers in the preparation of their lectures with the help of increasing awareness of students about ICT and their coordination for the transmission of teaching material. A positive effect will also generate in the students in terms of motivations and attitude towards the use of ICT in learning their subjects and technology. ICT allow the teachers and build a strong coordination in between the students and teachers by suing different tools to which the students familiar and comfortably used them in classroom and home as well. The important thing is the teachers' ability to integrate their teaching processes with ICT - based teaching strategy.

In the modern world physics and technology are very much integrated because the basic aim of the application of theology is to develop the understanding of man - made world which was supposed to be the 
offspring of physics. World Wide Web, invention of Semiconductor, Superconductor, Telecommunication, Mobile Phones sets are the examples in the development of in the field of Physics. Now a day's we can use and access almost all the internet facilities including phone calls by Android Phones in which different features are available in a phone set.

Physics is that breach of science that inspires the young people by intellectual adventures and expands the boundary of knowledge about nature (Trammel, Martians, 2014). It is also providing fundamental and basic knowledge for the development of technology which provide latest infrastructure and skilled man power to run the economic energy to the world.

Hussain, Azeem and Shakoor (2011) reported in their study about the physics teaching method that scientific inquiry method of physics teaching becomes significant as compare to traditional lecture method due to its significance. The traditional teaching method based on the class lectures focus on the basic definitions, concepts and derivations whereas the scientific inquiry method based on the concept development (Arif, Kamal, 2003). Scientific inquiry method introduces new technologies and ideas in the field of physics teaching. Scientific inquiry method leads to develop the understanding of physics students about its conceits and derivations. It also enhances the skills and attitude of students to solve their quires and issues to construct new knowledge (Joe, Exline, 2004).

William (1999) indicates that by sing ICT the research in the field of Physics becomes easy in terms of creative writing and incorporation of different topics by means of multi - media and simulations which can be helpful in outcome of teaching and learning.

Physics students are not taking interest in learning and understanding the fundamental concepts of physics and suppose that understanding of physics becomes difficult. We can easily transfer knowledge, develop skills and built confidence in the students in their learning process of physics by using Information and Communication Technology (Eliot Eisner, 1998, p.105). In Pakistani context due to the lack of interest and awareness Government authorities cannot play their role to update physics course as per the requirement of modern world so that the course out line and laboratories are not equipped with the required technologies. (Khalid, Rashid, 2005).

In the last decade, the research in education intensively searching new ideas and strategies to innovate the physics teaching approaches. In this aspect Information and Communication Technology (ICT) moralized the potential of teachers and students as well (Ivan, Simon, 2012).

Due to the above fact the application of Information and Communication Technology (ICT) in teaching physics develop their interest in understanding and learning not only fundamental concepts, but also helpful to understand complex phenomenon and theories with the help of different animations, slides and power point presentations. ICT - based physics teaching also helpful in the development of different projects because it is a source of content-based education.

\subsection{Statement of the Problem}

Students of $\mathrm{XI}$ and $\mathrm{XII}$ fail to understand the complex and difficult theories and phenomenon of physics and they suppose that it is a boring and difficult subject. Therefore by the application of Information and Communication Technology it can make interesting. ICT can facilitate the students to understand different topics and theories of physics because with the help of ICT physics teachers can show their students different animations and slides which can be helpful in developing key concepts.

\subsection{Objectives of the Study}

The objective of this study was to determine the perception of grade XI and XII public and private sector physics lecturer and subject experts for the application of Information and Communication Technology in teaching physics. Physics is that branch of science which deals with matter and its interaction with other matters.

\subsubsection{General objective}

The general objective of this study is to determine the perception of physics lecturer and subject experts about the placation of ICT in teaching physics.

\subsubsection{Specific objective}

The general objective is to determine the perception of grade XI and XII public and private sector physics 
lecturer and subject experts about the placation of ICT in teaching physics.

It was observed that students cannot understand the fundamental concepts easily. The main stake holder of this research was:

- Grade XI and XII physics students of public and private sector colleges and higher secondary schools of Karachi region.

- Physics lecturers and subject experts of grade XI and XII of public and private sector colleges and higher secondary schools of Karachi region.

Adeyemo in the year 2010, study the impact of Information and Communication Technology on teaching and learning questionnaire (ICTITLQ) with a questionnaire used as an instrument that information and communication technology have great impact not only on learning and teaching physics it makes it more interesting and easier to understand.

In $5^{\text {th }}$ Work shop on the use of Multimedia in teaching and learning physics (October $8^{\text {th }}$ to $10^{\text {th }}, 2000$, Vienna) Roth (2000) delivered a lecture about the importance of use of multimedia in teaching physics. According to him the use of ICT in teaching physics produce a great impact on the student's performance so students can easily design three dimensional presentations of their experiments under the supervision of their teachers and subject experts and enhance their learning skills and share their knowledge with other students.

\subsection{Research Questions}

The basic research questions of this research were

1. Is ICT - based physics teaching is more effective as compare to Non-ICT - based Physics teaching.

2. Does ICT - based physics teaching generate content - based learning interest in grade $\mathrm{XI}$ and XII Physics students.

\subsubsection{Hypothesis}

This research was formulated on the following hypothesis:

\section{Hypothesis 1}

There is no significant difference in the perception of grade XI and XII public and private sector physics teachers on the effectiveness of ICT in physics teaching.

\section{Hypothesis 2}

There is no significant difference in the perception of male and female grade XI and XII physics teachers on the ICT based physics teaching student's performance for their project development.

\section{Hypothesis 3}

There is no significant difference in the perception of male and female grade XI and XII experienced physics teachers for the explanation of complex articles with the help of ICT based physics teaching.

\subsection{Methodology}

The methodology used to collect data based on survey method and a questionnaire is used as an instrument for this research which is based on testing hypothesis and numerical data from the Physics lecturers and teachers of grade XI and XII of public and private sector colleges and higher secondary schools. The survey was based on quantitative research method. According to Johnson \& Christensen (2004) quantitative research method based on testing of collected data from hypotheses and numerical data.

\subsubsection{Target Population}

The target population for this research was the physics lecturers and subject experts of grade XI and XII of colleges and higher secondary public and private sector schools of Karachi region.

\subsubsection{Sampling Technique}

This research was based on the perception of grade XI and XII public and private sector colleges and higher secondary schools physics lecturers and subject experts based on Karachi region therefore the sample for 
this research were the physics teachers and subject experts of both public and private sector colleges and higher secondary schools of Karachi region. There are around 340 public and private sector colleges and higher secondary schools. The researcher randomly selected 200 public and private sector colleges and higher secondary schools of Karachi region in which 149 questionnaires are filled and return which is equal to $43.8 \%$ of sample.

\subsubsection{Participant's Characteristics}

The main characteristics of the participants of this research were:

- All participants were belonged to the female and male physics teachers' gender.

- All participants were belonged to the faculty of grade XI and XII physics teachers.

- All participants were belonged to the private and public sector grade XI and XII educational institutions of Karachi region.

- All the participants had Master's Degree in Physics.

Table 1 Teachers' Gender

\begin{tabular}{|l|l|c|c|c|c|}
\hline \multicolumn{2}{|l|}{} & Frequency & Percent & Valid Percent & $\begin{array}{c}\text { Cumulative } \\
\text { Percent }\end{array}$ \\
\hline Valid & Male & 80 & 53.7 & 53.7 & 53.7 \\
\hline & Female & 69 & 46.3 & 46.3 & 100.0 \\
\hline & Total & 149 & 100.0 & 100.0 & \\
\hline
\end{tabular}

In the above table 1, total numbers of teachers are 149 , in which $53.7 \%$ that is 80 responders were male and $46.3 \%$ that is 69 were female responders so that the ration is equal to $27: 23$.

Table 2 Institution type

\begin{tabular}{|l|l|c|c|c|c|}
\hline \multicolumn{2}{|l|}{} & Frequency & Percent & Valid Percent & $\begin{array}{c}\text { Cumulative } \\
\text { Percent }\end{array}$ \\
\hline Valid & Private & 70 & 47.0 & 47.0 & 47.0 \\
\hline & Public & 79 & 53.0 & 53.0 & 100.0 \\
\hline & Total & 149 & 100.0 & 100.0 & \\
\hline
\end{tabular}

In table 2, total numbers of public and private educational institutions were 149 , in which $47.0 \%$ were private educational institutions that is 70 in number and $53.0 \%$ were public sector educational institutions which is equal to 79 in number.

Table 3 Subject Specialty

\begin{tabular}{|l|l|c|c|c|c|}
\hline \multicolumn{2}{|l|}{} & Frequency & Percent & Valid Percent & $\begin{array}{c}\text { Cumulative } \\
\text { Percent }\end{array}$ \\
\hline Valid & Physics & 141 & 94.6 & 94.6 & 94.6 \\
\hline & Non-Physics / Other Sciences & 8 & 5.4 & 5.4 & 100.0 \\
\hline & Total & 149 & 100.0 & 100.0 & \\
\hline
\end{tabular}

In the above table 3 , with $\mathrm{N}=149$, frequency of 141 shows that $94.6 \%$ participants were physics teachers and frequency 8 shows the number of non-physics / other sciences teachers which was equal to $5.4 \%$ of overall sample. 
Table 4 Grade Level XI

\begin{tabular}{|l|l|c|c|c|c|}
\hline \multicolumn{2}{|l|}{} & Frequency & Percent & Valid Percent & $\begin{array}{c}\text { Cumulative } \\
\text { Percent }\end{array}$ \\
\hline Valid & XI & 138 & 92.6 & 100.0 & 100.0 \\
\hline Missing & System & 11 & 7.4 & & \\
\hline Total & 149 & 100.0 & & \\
\hline
\end{tabular}

The above table 4 shows that with $\mathrm{N}=149,138$ Physics teachers were taught only in Grade $\mathrm{XI}$ with $92.6 \%$ of the sample.

Table $5 \quad$ Grade Level XII

\begin{tabular}{|l|l|c|c|c|c|}
\hline \multicolumn{2}{|l|}{} & Frequency & Percent & Valid Percent & $\begin{array}{c}\text { Cumulative } \\
\text { Percent }\end{array}$ \\
\hline Valid & XII & 140 & 94.0 & 100.0 & 100.0 \\
\hline Missing & System & 9 & 6.0 & & \\
\hline Total & 149 & 100.0 & & \\
\hline
\end{tabular}

The above table 5 shows that with $\mathrm{N}=149,140$ physics teachers were taught only in Grade XII with $94.0 \%$ of the sample.

\subsection{Research Instrument}

The instrument which was used in this research was based on questionnaire. This questionnaire was based on the literature review and hypothesis. A 'Likert scale' with categories as strongly agree, agree, not sure, disagree and strongly disagree was used to determine the score of questionnaires.

Newman (2000) and Macmillan \& Schumacher (2001) states that the instrument which is used as a tool for any research was based on closed - ended questionnaire due to easy for answering with a large number of sample and so many items were involved in it.

The instrument used for this research consisted of two sections that is 'Demographic information' and 'teachers' perception'

\subsubsection{Demographic Information:}

The first section of the instrument was based on the respondents' demographic information such as age, gender, name of institute, the class taught, qualification, subject specialty, teaching load, length of Physics periods, grade level, teaching experience, salary.

\subsubsection{Teachers Perceptions:}

The second section of the instrument was based on teachers' perception with different items and options such as strongly agree, agree, neutral, disagree, and strongly disagree.

\subsection{Threats to Internal Validity and External Validity}

Validity of any instrument was based on the measurement of the instrument and what was supposed to be measured. For this purpose, the instrument provided to the experts for face and content validity.

Black (1999) states about the face validity that it is the way checking of validity of any instrument that response of any responder becomes valid and supposed to be check.' Johnson \& Christensen (2004) explains about the construct validity of any instrument that it is an act of judgment in which experts check the construct validity of any instrument in terms of scoring, wording, formatting etc,

On the basis of above discussion, the researcher considered the validity of instrument on the following basis: 

i) Criterion Validity
ii) Content Validity
iii)Constant Validity

Criterion validity based on using standard strategies for searching material and reference section from the relevant research journals and articles. It is important that collected data must be constructing to determine the valid out comes.

This research was based on the perception of grade XI and XII lecturers and subject experts of public and private sector Colleges and Higher Secondary Schools of Karachi region, therefore the researcher considers the following as threats of internal and external validity.

\subsubsection{Ethical Consideration}

The researcher ensures in the best possible extant about the ethical consideration in terms of mentioning the name of individual, institution name, gender, qualification, experience, designation, salary, age, contact number, E - mail address, etc.

\subsubsection{Legal Consideration}

Researcher also granted about the legal permission for the use of statistical data from the concern authorities and provides surety to the respondent about the collected data which is used only for the research purpose.

\subsection{Instrument Reliability}

Instrument reliability is based on the result of any primary instrument. If the result of primary instrument is same then it is known as 'Instrument Reliability' and it is measured by applying statistical measuring tools. For instrument reliability it is necessary that the data must be consistent for this purpose the researcher divided its instrument reliability in to three categories.

- Test - retest

- Equivalent form, and

- Internal consistency

\subsubsection{Cronbach's Alpha Test}

The researcher was used Cronbach's Alpha Test to measure the internal consistency of the instrument with an attitude instrument with 'Likert Scale'. This test used when the questions of the instrument not based on right vs. wrong.

\section{Reliability Statistics}

\begin{tabular}{|c|r|}
\hline $\begin{array}{c}\text { Cronbach's } \\
\text { Alpha }\end{array}$ & N of Items \\
\hline .746 & 21 \\
\hline
\end{tabular}

Table shows Cronbach's Alpha test for instrument reliability statistics. The teat for 21 numbers of items calculates the Cronbach's Alpha value is equal to 0.746 which is greater than the required value of 0.5 or $50 \%$ of the required value so that the instruments becomes reliable for research.

\subsection{Research Design and Procedure}

The research design and procedure adapted by the researcher was as follows:

\subsubsection{Selection of Sample}

This research was based on the perception of physics lectures and subject experts of grade XI and XII therefore the sample of this research was the grade XI and XII physics lecturers and subject experts of public and private sector colleges and higher secondary schools of Karachi region. This sample was selected randomly. 


\subsubsection{Procedure for data collection}

The procedure adapted by the researcher consists of following steps:

\section{- Pilot Study}

According to Cooper \& Schindler (2003) a good researcher must conducted a pilot study of their instrument to reshaping it if there is any confusion regarding questions and must consult with experts to rectify them. After checking the reliability test the researcher conducted a pilot study by filling the questionnaire with a sample of 20 teachers' with were not included in the research.

\section{- Survey Method}

After completing the pilot study and rectify all possible errors and confusion in the instrument the researcher used the survey method to collect the data randomly from the different Colleges and Higher Secondary Schools of the Karachi region and provide the questionnaire to the grade XI and XII Physics lecturers and subject experts and collected them after filling the respondents.

\subsection{Data Collection and Analysis}

\subsubsection{Data Collection}

After gathering the filled questionnaire from the respondents, researcher interpreted them by means of Likert - scale method. To find out the mean difference of each questionnaire researcher applied SPSS 15.0 version and apply weighted man and One Sample T - Test. The weighted mean represents the significance of questions with a standard value. Demographic data or information also interpreted by the applying of SPSS 15.0 version.

\subsubsection{Data Analysis}

Q1) ICT- based Physics teaching is comparatively more effective.

Table 1.10.1

\begin{tabular}{|l|l|c|c|c|c|}
\hline \multicolumn{2}{|l|}{} & Frequency & Percent & Valid Percent & Cumulative Percent \\
\hline Valid & Strongly Disagree & 0 & 0 & 0 & 0 \\
\hline & Disagree & 1 & .7 & .7 & .7 \\
\hline & Not Sure & 5 & 3.4 & 3.4 & 52.3 \\
\hline & Agree & 72 & 48.3 & 48.3 & 100.0 \\
\hline & Strongly Agree & 71 & 47.7 & 47.7 & \\
\hline & Total & 149 & 100.0 & 100.0 & \multirow{2}{*}{} \\
\hline
\end{tabular}

Table 1.10.1, shows that with frequency of 72 and valid percentage $48.3 \%$ of college and higher secondary school, lecturers and subject experts are agreed that ICT - based Physics teaching is more effective as compare to Non - ICT based Physics teaching. With frequency 71 and valid percentage $47.7 \%$ of college and higher secondary school lecturers and subject experts are strongly agreed that ICT based Physics teaching is more effective as compare to Non-ICT - based Physics teaching. Frequency 5 and 1 represents with valid percentage only $3.4 \%$ and $0.75 \%$ of college lecturers and higher secondary school subject experts are not sure and disagree with the statement respectively.

It is also observed from the table 1.10.1, that there is no significance difference in the perception of college lecturers and higher secondary school subject experts in sense of agree and strongly agree for the statement represented by $48.3 \%$ and $47.7 \%$ of the sample respectively. 


\subsubsection{One-Sample Statistics}

Table 1.10.2

\begin{tabular}{|l|c|c|c|c|}
\hline & $\mathrm{N}$ & Mean & $\begin{array}{c}\text { Std. } \\
\text { Deviation }\end{array}$ & $\begin{array}{c}\text { Std. Error } \\
\text { Mean }\end{array}$ \\
\hline $\begin{array}{l}\text { ICT based Physics } \\
\text { Teaching Effect }\end{array}$ & 149 & 4.4295 & .59565 & .04880 \\
\hline
\end{tabular}

Table 1.10.2, reflects that with $\mathrm{N}=149$ the mean of intensity scale is 4.4295 and Standard deviation is 0.59565 . The Standard Error of the mean is 0.04880 .

Q2) ICT generates more content-based interest in students in learning physics.

Table 1.10.3

\begin{tabular}{|l|l|c|c|c|c|}
\hline \multicolumn{2}{|l|}{} & Frequency & Percent & Valid Percent & $\begin{array}{c}\text { Cumulative } \\
\text { Percent }\end{array}$ \\
\hline \multirow{2}{*}{ Valid } & Strongly Disagree & 0 & 0 & 0 & 0 \\
\hline & Disagree & 3 & 2.0 & 2.0 & 2.0 \\
\hline & Not Sure & 10 & 6.7 & 6.7 & 8.7 \\
\hline & Agree & 75 & 50.3 & 50.3 & 59.1 \\
\hline & Strongly Agree & 61 & 40.9 & 40.9 & 100.0 \\
\hline & Total & 149 & 100.0 & 100.0 & \\
\hline
\end{tabular}

Table 1.10.3, reflects that with frequency of 75 and valid percentage $50.3 \%$ of college and higher secondary school, lecturers and subject experts respectively are agreed that ICT - based physics teaching generates more content - based interest in students in learning physics as compare to Non - ICT based physics teaching. With frequency 61 and valid percentage $40.9 \%$ of college and higher secondary school lecturers and subject experts are strongly agreed that ICT based physics teaching generate more content - based interest in students in learning physics as compare to Non-ICT based physics teaching. Frequency 10 and 3 represents that $6.7 \%$ and $2.0 \%$ of college lecturers and higher secondary school subject experts are not sure and disagree with the statement.

\subsubsection{One-Sample Statistics}

Table 1.10.4

\begin{tabular}{|l|c|c|c|c|}
\hline & $\mathrm{N}$ & Mean & $\begin{array}{c}\text { Std. } \\
\text { Deviation }\end{array}$ & Std. Error Mean \\
\hline $\begin{array}{l}\text { Interest in } \\
\text { learning } \\
\text { physics }\end{array}$ & 149 & 4.3020 & .68482 & .05610 \\
\hline
\end{tabular}

Table 1.10.4, reflects that with $\mathrm{N}=149$ the mean of intensity scale is 4.3020 and Standard deviation is 0.68482 . The Standard Error of the mean is 0.05610 .

\section{Hypothesis 01}

There is no significant difference in the perception of public and private sector Grade XI and XII physics teachers on the basis of effectiveness of ICT in teaching physics. 


\subsubsection{Group Statistics}

Table 1.10.5

\section{Group Statistics}

\begin{tabular}{|ll|r|r|r|r|}
\hline & Private and Public & & & & Std. Error \\
& Education Sector & $\mathrm{N}$ & Mean & Std. Deviation & \multicolumn{1}{c|}{ Mean } \\
\hline Effectiveness of ICT & Private & 70 & 4.4429 & .60519 & .07233 \\
& Public & 79 & 4.4177 & .59069 & .06646 \\
\hline
\end{tabular}

Table 1.10.5, shows the public and private sector Grade XI and XII physics teachers' perception about the effectiveness of ICT in teaching physics of the desired research sample of Karachi region. Table 1.10.5, shows that with $\mathrm{N}=70$, the mean of private sector physics teachers' in the group is 4.4429 and with $\mathrm{N}=79$, the mean of public sector physics teachers' in the group is 4.4177 . The standard deviation for the private sector physics teachers' in the sample is 0.60519 where as the standard deviation for the public sector physics teachers' in the sample is 0.59069 . Similarly, the standard error mean of the private sector physics teachers in the sample is reads as 0.07233 and the standard error mean of the public sector physics teachers' in the sample is reads as 0.06646 .

\subsubsection{Independent Sample test}

Table 1.10.6

\begin{tabular}{|c|c|c|c|c|c|c|c|c|c|c|}
\hline \multicolumn{11}{|c|}{ Independent Samples Test } \\
\hline & & \multicolumn{2}{|c|}{$\begin{array}{l}\text { Levene's Test for } \\
\text { Equality of Variances }\end{array}$} & \multicolumn{7}{|c|}{ t-test for Equality of Means } \\
\hline & & \multirow[b]{2}{*}{$\mathrm{F}$} & \multirow[b]{2}{*}{ Sig. } & \multirow[b]{2}{*}{$t$} & \multirow[b]{2}{*}{ df } & \multirow[b]{2}{*}{ Sig. (2-tailed) } & \multirow{2}{*}{$\begin{array}{c}\text { Mean } \\
\text { Difference }\end{array}$} & \multirow{2}{*}{$\begin{array}{l}\text { Std. Error } \\
\text { Difference }\end{array}$} & \multicolumn{2}{|c|}{$\begin{array}{l}95 \% \text { Confidence } \\
\text { Interval of the } \\
\text { Difference }\end{array}$} \\
\hline & & & & & & & & & Lower & Upper \\
\hline Effectiveness of ICT & $\begin{array}{l}\text { Equal variances } \\
\text { assumed }\end{array}$ & 011 & .915 & .256 & 147 & .798 & .02514 & . 09808 & -16870 & .21897 \\
\hline & $\begin{array}{l}\text { Equal variances } \\
\text { not assumed }\end{array}$ & & & .256 & 143.931 & .798 & .02514 & .09823 & -.16902 & .21929 \\
\hline
\end{tabular}

Table 1.10.6 shows Levene's test for quality of variances and t-test for equality of means. The sig. value is greater than 0.05 , therefore the researcher conclude that there is no significant difference in the perception of government and private sectors teachers in context of ICT effectiveness.

\section{Hypothesis 02}

There is no significant difference in the perception of Grade XI and XII male and female physics teachers on the basis of project development performance of ICT in teaching physics.

\subsubsection{Group Statistics}

Table 1.10.7

\section{Group Statistics}

\begin{tabular}{|ll|r|r|r|c|}
\hline & Teacher Gender & $\mathrm{N}$ & Mean & Std. Deviation & $\begin{array}{c}\text { Std. Error } \\
\text { Mean }\end{array}$ \\
\hline ICT is Helpful in & Male & 80 & 4.0875 & .71501 & .07994 \\
Project Development & Female & 69 & 4.2464 & .65092 & .07836 \\
\hline
\end{tabular}

Table 1.10.7 shows the group statistics of the Grade XI and XII physics teachers' gender for their perception about helpfulness of ICT in project development as a research sample for Karachi region. With $\mathrm{N}=80$, the mean of male physics teachers of Grade XI and XII is 4.0875 and with $\mathrm{N}=69$, the mean of female physics teachers of Grade XI and XII is 4.2464 of the sample. The standard deviation of the Grade XI and XII male physics teachers is equal to 0.71501 where as the standard deviation of the Grade XI and XII female physics teachers is equal to 0.65092 same as the standard error mean of the Grade XI and XII male physics 
teachers is 0.07994 and for grade XI and XII female physics teachers becomes 0.07836 of the sample.

\subsubsection{Independent Sample Test}

Table 1.10.8

\begin{tabular}{|c|c|c|c|c|c|c|c|c|c|c|}
\hline \multicolumn{11}{|c|}{ Independent Samples Test } \\
\hline & & \multicolumn{2}{|c|}{$\begin{array}{c}\text { Levene's Test for } \\
\text { Equality of Variances }\end{array}$} & \multicolumn{7}{|c|}{$\mathrm{t}$-test for Equality of Means } \\
\hline & & \multirow[b]{2}{*}{$\mathrm{F}$} & \multirow[b]{2}{*}{ Sig. } & \multirow[b]{2}{*}{$\mathrm{t}$} & \multirow[b]{2}{*}{ df } & \multirow[b]{2}{*}{ Sig. (2-tailed) } & \multirow{2}{*}{$\begin{array}{c}\text { Mean } \\
\text { Difference }\end{array}$} & \multirow{2}{*}{$\begin{array}{l}\text { Std. Error } \\
\text { Difference }\end{array}$} & \multicolumn{2}{|c|}{$\begin{array}{l}95 \% \text { Confidence } \\
\text { Interval of the } \\
\text { Difference }\end{array}$} \\
\hline & & & & & & & & & Lower & Upper \\
\hline \multirow[t]{2}{*}{$\begin{array}{l}\text { ICT is Helpful in } \\
\text { Project Development }\end{array}$} & $\begin{array}{l}\text { Equal variances } \\
\text { assumed }\end{array}$ & .374 & .542 & -1.409 & 147 & .161 & -.15888 & .11272 & -.38165 & .06389 \\
\hline & $\begin{array}{l}\text { Equal variances } \\
\text { not assumed }\end{array}$ & & & -1.419 & 146.556 & .158 & -.15888 & .11194 & -.38011 & .06235 \\
\hline
\end{tabular}

Table 1.10 .8 is the Levene's test for equality of variances and $t$ - test for equality of means. The sig. value is greater than 0.05 , therefore the researcher conclude that there is no significant difference in the perception of grade XI and XII male and female physics teachers for project development performance by using ICT in physics teaching.

\section{Hypothesis 03}

There is no significant difference in the perception of grade XI and XII male and female experience physics teachers on the basis of explanation of complex articles by using ICT.

\subsubsection{Group Statistics}

Table 1.10 .9

\section{Group Statistics}

\begin{tabular}{|ll|r|r|r|r|}
\hline & Teacher Gender & N & Mean & Std. Deviation & $\begin{array}{c}\text { Std. Error } \\
\text { Mean }\end{array}$ \\
\hline $\begin{array}{l}\text { ICT facilitates } \\
\text { students in expalining } \\
\text { complex articles }\end{array}$ & Male & 80 & 4.2375 & .75042 & .08390 \\
\hline
\end{tabular}

Table 1.10.9, represents the group statistics of male and female Grade XI and XII physics lecturers and teachers of Karachi region for this research sample. With $\mathrm{N}=80$, the mean value of grade XI and XII male physics teachers reads as 4.2375 with standard deviation of 0.75042 where as the standard error mean for this group of teachers reads as 0.08390 . With $\mathrm{N}=69$, the mean value of Grade XI and XII female physics teachers reads as 4.2319 and standard deviation is 0.75039 where as the standard error mean for this group of teachers reads as 0.09034 with respect of the sample.

\subsubsection{Independent Sample Test}

Table 1.10.10

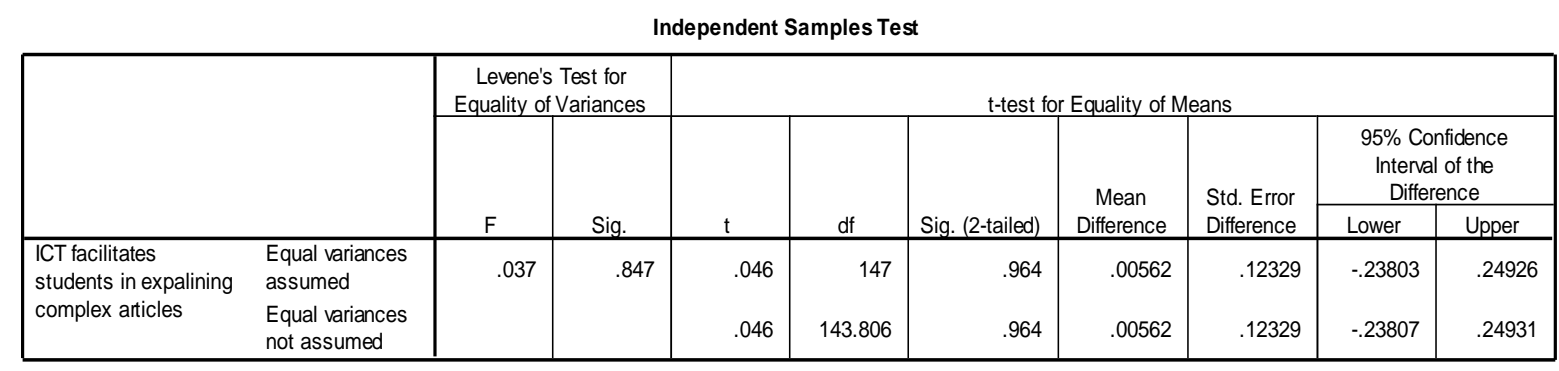

Table 1.10.10, elaborates the Levene's test for equality of variances and $t-$ test for equality of means. In Levene's test for equality of variances the sig. value is greater than 0.05 which reflects that there is no 
significant difference in the perception of grade xi and xii male and female physics lecturers and subject experts in the explanation of complex articles with the help of ICT.

\subsection{Findings}

The major findings of this research are as follows:

Q1) ICT- based physics teaching is comparatively more effective.

From the table 1.10.1 it is elaborating that most of the grade XI and XII public and private sector physics teachers of Karachi region agreed that ICT based physics teaching is more effective as compare to Non ICT based physics teaching.

Q2) ICT generates more content-based interest in students in learning physics.

The table 1.10.3 indicates that the lecturers and teachers of grade XI and XII public and private sector colleges and higher secondary schools are agreed that ICT - based physics teaching generates more content - based interest in students in learning physics as compared to Non - ICT based physics teaching.

\section{Hypothesis 1}

The outcome of hypothesis 1 according to the obtained value of ' $F$ ' from Levene's test for the equality of variance found that the value of variance is greater than the value of critical region. Therefore, it is clear that the lecturers and subject experts of grade XI and XII of public and private sector colleges and higher secondary schools are strongly agreed that the ICT - based physics teaching is more effective as compare to the Non - ICT based physics teaching. Therefore hypothesis is uphold.

The group statistics table 1.10 .5 finding also becomes an evidence of the statement.

\section{Hypothesis 2}

The outcome of Levene's test for hypothesis 2 for the equality of variances indicates that the value of ' $F$ ' is greater than the value for critical region value of 0.05 , therefore the finding of the statement of hypothesis based on the perception of grade XI and XII male and female physics lecturers and subject experts is that they are strongly agreed that ICT - based physics teaching becomes more help full in their project development performance. Table 1.10 .7 of group statistics responders' response also indicates that they are strongly agreed with the statement so the hypothesis becomes uphold.

\section{Hypothesis 3}

The outcome of the hypothesis from the Levene's test for the equality of variances indicates that the value of ' $F$ ' is greater than the 0.05 that is from the critical region value so that the statement of the physics lecturers and subject experts of public and private sector grade XI and XII that ICT - based Grade XI and XII physics teaching becomes helpful in explaining the complex articles of physics is in the strongly agreed category which shoes that the hypothesis becomes uphold. From the table 1.10 .9 of the group statistics also shows that the respondents are in the strongly agreed category and the test becomes insignificant.

\subsection{Discussion}

This research was conducted to determine the perception of grade XI and XII public and private sector colleges and higher secondary schools male and female physics lecturers and subject experts of Karachi region and all the educational institutes are affiliated with the Board of Intermediate Education, Karachi. The course outline for the teachers and students is same as per the book recommended by Sindh Text Book board, Government of Sindh.

From the statistical analysis of the collected data it was observed and determined that the respondents of research are agreed that application of ICT - based physics teaching for grade XI and XII of public and private sector colleges and higher secondary schools lecturers and student becomes very help full in teaching and learning for both lecturers, subject experts and students as the lecturers and subject experts can deliver their lecturers and teach the students more comfortably on the other hand students can understand easily as compare to traditional teaching practice in which theoretical based concepts and complex phenomenon create difficulties in delivering lecturer and understanding. Not only this it can also helpful in the development of fundamental concepts so the students can develop their projects by using its different software's in three directional programming, by using statistical tool students can easily calculate and analyze their research work. 
Overall results of the study shows that the application of ICT - based physics teaching and learning becomes very help full as compare to traditional teaching practice to develop the understanding of lecturers, subject experts and students for the improvement of teaching and learning for our local context.

\subsection{Conclusions}

From this research the researcher concluded that ICT - based physics teaching and learning for grade XI and XII physics lecturers, subject experts and students becomes more effective as compare to traditional based teaching and learning. It can also be help full to enhance the academic achievement not only their academic performance on current stage but also help full in their higher studies in every field specially in the field of science and research. By using Information and Communication Technology as teaching tool the physics lecturers and subject experts of can enhance the student's senseless memorization to develop understanding with pleasure.

\subsection{Recommendations}

The recommendations of the researcher are as follows:

- In the light of research, researcher recommended that grade Xi and XII physics teachers of public and private sector educational institutes and their management need to incorporate the fascinating experiences of ICT - based physics teaching in their colleges and higher secondary schools across the province of Sindh.

- Researcher also recommended to the Government of Sindh, Education and Literacy Department, Government of Sindh, Directorate of Education, Government of Sindh, The Bureau of Curriculum, Government of Sindh and all other concern authorities to play their role in the implementation of ICT - based physics teaching and learning in colleges and higher secondary schools. For this purpose, it is the responsibility of the concern authorities to provide the basic facilities to the educational institutions such as computers, internet, skill and experience lecturers and subject experts, teachers training programs and workshops are also very helpful for the lecturers and subject experts to enhance their professional skill for betterment of students and country.

\section{REFERENCE LIST}

Adeyemo, S. A. (Phd). (2010). The Impact of Information and communication Technology (ICT) on the Teaching and Learning of Physics . Society of Education. India.

Akintunde, Z .T. \& Aina J.K. (2013). Analysis of gender performance in Physics colleges of education, Nigeria. Journal of education and practice, 4(6). doi: ISSN 2222 - 288X.[8].

Aigbomian, D.O. (1994). Student's perception of technical words in the learning physics . Studies in education 2(1), 86 - 92 [5].

Aiyelabegan, T.A. (2003). Effect of physics on students' academic performance in senior school certificate examination in Kwara State. Lafiagi journal of Science Education.1\& 2,3,4 [9].

Akanbi, A,O. (2003). An investigation into students' performance in senior school physics . Journal of Teachers Education Trends. 1(1), 58 - 64 [11].

Adeyemo, S.A. (2010). Teaching / learning physic in Nigerian secondary school: The curriculum transformation, issues, problems and prospects. International journal of Educational Research and Technology, 1 (1), 99 - 111 [4].

Chalopatham, W., Phon-noi, W. \& Ployduangrat, J. (2015). A study of Information Communication Technology (ICT) competency for students of teaching profession. $20^{\text {th }}$ International Academic Conference, Madrid.

Comi, S., Gui, M., Origo, F., Pagani, L. \& Argentin, g. (2016). Is it the way they use it? Teachers, ICT and student achievement. Dems working paper series. Department of Economics, Management and Statistics, University of Milan - Bicocca.

Hussain, A. Dr., Azeem, M. \& Shakoor, A. (2011). Physics teaching method: Scientific inquiry vs traditional lecture. International Journal of Humanities and Social Science. vol. 1 (19). 
Ivan, G., Simon, U. (2012). The conceptual learning of physics in Slovenian Secondary Schools. International Journal for Research in Vocational Education and Training (IJRVET).vol. (45) [3] pp. 140 $-144$.

Jin, S., Lee, J., (2015). Identifying ICT - based core competencies for educating gifted students in science. $17^{\text {th }}$ International Academic Conference, Vienna. Gyeongin National University of Education, South Korea.

Jarosievitz, B. Dennis Gabor College SEK Budapest International School (Hungary). E-mail: Jarosievitz@ gdf.hu

Lim, C.P. (2007). Effective integration ICT in Singapore Schools: Pedagogical and Policy Implications. Educational Technology Research and Development, 55(1), 83 - 116. Retrieved from http://www.jstor.org/stable/30221231

Olosunde, G.R,, Oladejo, M.A., Isola, O.M. \& Ojebisi, A.O. (2011). Instructional material and students' academic achievement in physics : some policy implications. European journal of Humanities and Social Sciences,2(1), doi : ISSN 2220 - 94

Roth, D. (2000). Use of Multimedia for the Presentation in Physics Students Lab. Department of Physics . University of Kaiserslautern, Kaiserslautern. $5^{\text {th }}$ Work shop on Multimedia in Physics Teaching and Learning. Vienna.

Schauer, F., Cernansky, P., Ozvoldova, M., Lusting, F. (2007). Integrated e-learning. New strategy of the cognition of real world in teaching physics. Retrieved from https://www.researchgate.net/publication/268257327.

Trammel, B., Martians, K., (2014). Physics Curriculum for the $21^{\text {st }}$ Century. Eotvos Lorand University. Budapest, Hungary. Interdisciplinary Description of Complex Systems. 12 (2), 176 - 186

Vavougios, D., \& Krakasidis, T.(2008). Application of ICT Technology in Physics Education: Teaching and Learning Elementary Oscillations with the Aid of Simulation Software. International Journal of Emerging Technology in Learning (iJET).

Holubova, R., Kainzova, V., Riha, J., Vysin, I. (2008). Education of teachers in ICT application for teaching physics at primary and secondary schools. Problems of education in the $21^{\text {th }}$ century, Vol 9. Palaky University Olomouc, Czech Republic. 